\author{
Szakolczai Attila PhD
}

szakolczai56@gmail.com

történész (Budapest)

\title{
Közvetlen és képviseleti demokrácia 1956-ban
}

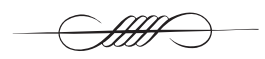

\section{— Direct and parliamentary Democracy in 1956 -}

Aвstract Recently, it has been argued by many that what happened in Hungary in 1956 may not be defined as a revolution, as the intention was not to create something new but to restore (with modifications) an earlier state. However, the present paper argues that in 1956 (along with - and, to be more precise, also closely related to - a war of freedom for national independence and sovereignty) there was a revolution in Hungary. It was a socialist revolution, which aimed at workers' taking power in their own hands and exercise power themselves. At the same time, the Hungarian October was a return to the era of labor movement before Bolshevik expropriation. This co-existence of direct and representative democracy was to accompany the dual (or rather triple) nature of ownership structure. The nationalization of mines, banks and industries (and the restoration of large estates) was not an issue in 1956. However, serious changes started to occur in the ownership structure of the means of production. Consequently, 1956 is to be considered a revolution.

KeYwords democracy, 1956 revolution, parliamentary democracy, direct democracy, dual ownership

DOI 10.14232/belv.2017.1.1

https://doi.org/10.14232/belv.2017.1.1

Cikkre való hivatkozás / How to cite this article:

Szakolczai Attila (2017): Közvetlen és képviseleti demokrácia 1956-ban. Belvedere Meridionale 29. évf. 1. sz. 5-23. pp

ISSN 1419-0222 (print)

ISSN 2064-5929 (online, pdf)

(Creative Commons) Nevezd meg! - Így add tovább! 4.0 (CC BY-SA 4.0)

(Creative Commons) Attribution-ShareAlike 4.0 International (CC BY-SA 4.0)

www.belvedere-meridionale.hu 
Úgy látom, a rendszerváltozás idején tévúton indult el az 1956-os forradalom és szabadságharc megismerését célul tűző történeti kutatás. (Azt megelőzően pedig - a források többségének hozzáférhetetlensége miatt - lehetőség sem volt rendszeres, vagyis tudományos kutatásra.) Az ellenforradalom tévútján, amit a megtorlás idején fabrikált dokumentumok, és az azokra, azokból építkező kádárista narratíva jelölt ki. Pedig ma már egyre nyilvánvalóbb, hogy a forradalom történetének legfontosabb forrásaként használt peres iratok nem az 1956-ban történtek elbeszéléseit tartalmazzák, hanem jobb esetben a történteknek a valóban történtekre alig hajazó torzításait, a történtek büntethető elemeit, gyakran pedig légből kapott konfabulációkat. Nem is lehet másként, hiszen az igazságszolgáltatási szervek feladata nem a történtek rekonstrukciója, hanem a pártvezetés kiszolgálása, a még a rendőrségi vizsgálatok érdemi megkezdése előtt, 1956. december 5-én a történteket ellenforradalomnak deklaráló párthatározat igazolása és utólagos adatolása volt. ${ }^{1}$ Ezekből a szándékoltan torz vagy hamis dokumentumokból rakták össze az „1956-os ellenforradalom” történetét a Kádár-kor udvari történetírói, akik közül többen már a források keletkeztetésében is meghatározó szerepet játszottak, leginkább a politikai rendőrség egyik osztályvezetője, Hollós Ervin. Kártékony tevékenységüket nem volt képes korrigálni az emigráció, amely el volt zárva a források nagy többségétől, így a Nyugatra kijuttatott néhány iraton kívül csak saját emlékezetére és mások emlékezéseire, valamint a kádárista irodalom által feltárt és dokumentumokkal alátámasztott „tényekre” hagyatkozhatott, amikor megpróbált szakszerü, egyben demokratikus igényű rekonstrukciót szembeállítani a reszovjetizált Magyarországon hivatalossal. A rendszerváltozáskor ezek az akkor nagy példányszámban kiadott munkák, elsősorban Gosztonyi Péter, Méray Tibor és Molnár Miklós könyvei ${ }^{2}$ adták azt az alapot, amelyen a forrásokhoz, többnyire és legfontosabbnak tartottként a peres iratokhoz végre egyre inkább hozzáférő kutatómunka elindulhatott. Mivel a „puszta tényeket” tekintve az emigráns szerzők írásai egybecsengtek a kádárista szövegekkel, valamint a végre hozzáférhetővé lett peres iratok kínálta információkkal és a veteránok visszaemlékezéseivel, egy-két korrekciót leszámítva elégnek tűnt az addigi narratívának a demokratikus normákhoz (és elvárásokhoz) igazítása: az ellenforradalmi bűncselekmények forradalmi tettként való bemutatása. Akaratlan cinkossággal átvettünk olyan kádárista „történelmi tényeket”, mint hogy októberben fegyveres csoportok vették fel a harcot a szovjet csapatokkal; az ő sikerük eredménye a forradalom október 28-i győzelme; belőlük alakult meg a nemzetőrség, amelynek célja a várható szovjet támadással szembeni honvédelem volt. Hogy október 30-án a Köztársaság téren a budapesti pártbizottság székházát ostromolták meg; hogy a munkástanácsok tevékenysége november 4. előtt kimerült a forradalmi követelések sztrájkkal támogatásában stb. Ezek mindegyike tartalmaz egy-egy vagy akár több valódi elemet, a József Attila-i értelemben mégsem igaz egyik sem.

Másfelől a rendszerváltozás idején, érthetően, a klasszikus hidegháborús kontextus határozta meg az ötvenhatos kutatásokat. Azok annak feltárására, pontosítására törekedtek, hogy milyen szerepe, milyen hatása volt a magyar forradalomnak a bipoláris világra, hogyan viszonyult, hogyan reagált a nagyvilág a forradalomra, az milyen helyet foglalt el a két szuperhatalom küzdelmében. A kutatások horizontját meghatározta - egyben behatárolta, leszükítette - a történteknek a XX. század dichotómiáján alapuló, diktatúrák és demokráciák szembenállására koncentráló vizsgálata. Annál is inkább, mert ötvenhat fontos eszköz volt a szovjet típusú diktatúra lebontásában. A megtorlás áldozatainak ünnepélyes temetése mutatta meg leghitelesebben és közérthetőbben a rendszer embertelenségét, amely egyben népszavazás volt a demokrácia, a

\footnotetext{
1 Zinner 2001. 52.; TAKÁcs 2010.; Hódos 2005. 140.

2 Gosztonyi 1989.; Méray 1989.; Molnár 1991.
} 
jogállam, az emberi normák helyreállítása mellett. Ezen a téren nem lehetett forradalmian új eredményekre jutni: már az 1990 előtt (Nyugaton) született munkák egyértelmüen kijelölték a magyar forradalom helyét a szovjet típusú (totális) diktatúra ellenfeleinek demokratikus táborában. A bipolaritás azonban nemcsak demokrácia és diktatúra, hanem egyben a kapitalista piacgazdaság és a szocialista (magát szocialistának állító) tervutasításos rendszer között feszült. Nem ismerek olyan tudományos munkát, amely kellően adatoltan azt bizonyítaná, hogy ötvenhat a kapitalista gazdasági-társadalmi rend restaurációjára irányult - de olyat sem, amely ennek ellenkezőjét állítaná, hogy a cél a szocializmus megőrzése lett volna, természetesen a rendszer alapjáig hatoló korrekciókkal. Ennek következtében a forradalom kétségtelenül demokratikus volta mindenestül a demokráciák táborába vonta ötvenhatot, amely így a hidegháborús logika alapján nem csupán diktatúraellenesnek, hanem a szocializmust is elutasítónak, antikommunistának tünik. Máig eleven, sőt, a hatvanadik évfordulón kiemelt helyet kapott a forradalomnak ez az antikommunista hagyománya. Pedig egyetlen olyan, 1956-ban ismert és elismert szervezet sem ismeretes, egyetlen ilyet nem tudott felmutatni sem a forradalom utáni megtorlás, sem a kádárista irodalom, sem a rendszerváltozás óta folyó kutatások, amely a piacon és a termelöeszközök magántulajdonán alapuló, vagyis kapitalista társadalmi-gazdasági rend visszaállítását követelve a szocializmust támadta volna. Ötvenhat esetleges kapitalista orientációjának feltételezése nem az 1956-ban történteken, nem azok beható elemzésén, hanem egyfelöl a történtek hibás leegyszerúsítésén alapul. Kétségtelen, hogy a megmozdulás a magát kommunistának állító párt diktatúrája ellen irányult, ellenfelei magukat kommunistának tekintették, de ez nem jelenti, hogy ötvenhat tábora, vagy annak meghatározó része magát a kommunista eszmét, a kizsákmányolástól és szükségtől mentes, egyenlőségre törekvő társadalmi berendezkedést is elutasította volna. Jól mutatja ezt, hogy akkor nem bíbelődtek volna a párt demokratikus átalakításának követelésével; nem tárgyaltak volna a helyi és országos pártszervekkel, hanem igyekeztek volna akadályozni, megakadályozni, netán betiltani a müködését. Ezzel szemben a városokban alig találni olyan forradalmi testületet, amelyben, sokszor annak vezetőségében ne lettek volna kommunista párttagok.

Másfelöl ötvenhat kapitalista orientációjának feltételezése a XX. század bipoláris világán alapul, ahol egyik táborban sem létezett kakukktojás: a nyugati demokratikus világban nem volt szocialista ország, a keleti blokkban pedig kapitalista. Ez volt a nyilvánvaló és egyértelmü vízválasztó, hiszen az egyes országok kapitalista vagy szocialista rendjét alaptörvény és törvények sokasága szabályozta, míg a hatalomgyakorlás tekintetében voltak különbségek az egyes táborokon belül: Nyugaton egy ideig léteztek jobboldali diktatúrák, Keleten pedig sztálinista diktatúrák vagy annál enyhébbek, ha úgy tetszik: a társadalomnak egy kevés szabadságot meghagyók. Végül az ötvenhatos antikommunista hagyomány azon a valós tényen alapul, hogy soha nem létezett olyan ország, amely egyszerre lett volna demokratikus és szocialista. (Talán Salvador Allende Chiléjét leszámítva, de a chilei kísérlet tragikus sorsa is azt mutatja, hogy a hidegháború nem adott teret efféle külön utaknak.) Ha tehát ötvenhat demokratikus volt, akkor, úgy tünik, nem lehetett szocialista.

A rendszerváltozás óta folyó kutatások tehát nem hoztak újat azon túl, hogy megállapították (amit már 1990-ben törvénybe is foglaltak, vagyis hasonlóan kanonizáltak, mint tette 1956 decemberében az MSZMP IKB): 1956-ban nemzeti szabadságharc és forradalom zajlott. Bár ezt a második megnevezést szakmai alapon többen vitatják, ${ }^{3}$ azt csupán néhány szakmai súllyal nem rendelkező szerző, hogy a változásért küzdők tábora a szovjet típusú egypárti diktatúra

\footnotetext{
${ }^{3}$ GYÁNi 2007. 48.
} 
felszámolására törekedett, annak felváltására egy többpárti, demokratikus modellel, ami az ország politikai berendezkedését tekintve forradalmi jellegű változást: a társadalom szabadságának nagymérvü növekedését eredményezte volna. Ötvenhatot pedig elsődlegesen azért tekintik demokratikusnak, mert már a müegyetemi pontokban, amit a forradalom általánosan elfogadott programjának lehet tekinteni, szerepelt a több párt részvételével tartott szabad választások követelése, ami mellett november 4. előtt és egy ideig még utána is kiállt majdnem minden forradalmi szervezet. Ebböl fakad a következtetés, miszerint ötvenhat célja, győzelem esetén akart vagy akaratlan eredménye a nyugati típusú, képviseleti demokrácia visszaállítása lett volna, hiszen „a demokrácia egyetlen lehetséges formája a szabad, éspedig több párt közötti szabad választáson alapuló parlamentáris demokrácia" "Valami olyasmi, ami a háború vége és a fordulat éve között volt. Már 1992-ben úgy látta Szabó Miklós, hogy ötvenhat politikai modellje a „nyugati demokráciák pluralista, többpártrendszeres, parlamenti modellje lett volna." "I Igy látja Nagy Imre és ötvenhat legtekintélyesebb kutatója, Rainer M. János is: „A forradalom politikai programja alapvetően nyugati mintájú demokráciát tartalmazott, annak intézményes és jogi kellékeivel együtt." (Azt többen jelezték, hogy a munkástanácsok, az önigazgatás jelenléte valamelyest átírta ezt a nyugati modellt. ${ }^{7}$ Eddig a leghangsúlyosabban Ripp Zoltán figyelmeztetett arra, hogy ötvenhat trendjébe a képviseletin túl a közvetlen demokrácia is beletartozott. ${ }^{8}$ ) Amennyiben viszont a forradalom célja vagy akaratlan eredménye a polgári demokrácia restaurálása lett volna, akkor igaza van Gyáni Gábornak, hogy ötvenhat „nem minősíthető tehát minden további nélkül forradalomnak a kifejezés modern (ideologikus) értelmében, legföljebb revolutiónak. ${ }^{9}$

Úgy látom azonban, hogy nem kellően megalapozott a pártok szabad müködésének követeléséből levont következtetés. Egyfelől azért, mert a nyugati típusú demokrácia polgári demokrácia, amely eddig sehol nem létezett magántulajdona révén egzisztenciális önállósággal rendelkező polgárság nélkül, márpedig 1956-ban Magyarországon nem létezett polgárság. Az egyetlen, termelőeszközt tulajdonló, létszámát tekintve jelentősebb társadalmi réteg, a kisbirtokos parasztság életmódját, hagyományait, politikai kötődéseit tekintve aligha nevezhető annak, miközben az eddigi kutatások nem tártak fel olyan speciális paraszti célokat, amelyek érdemben különböztek volna a városi értelmiség vagy munkásság által összeállított pontoktól. ${ }^{10}$ Ellenkezőleg. A falvak valamely közeli nagyváros programját fogadták el, azt toldották meg néhány helyi vonatkozású, a parasztság speciális követeléseinek hangot adó ponttal. Ezek az appendixek azonban soha nem irányultak a falu határain túlra. Helyi sérelmek orvoslását célozták, közük sem volt az ország társadalmi vagy politikai rendjéhez. A polgári demokráciát tehát csak egy legfeljebb majdan megszülető polgárság vívhatta volna ki - a jól szervezett, és politikailag öntudatos, magabiztos munkásság, és az azt támogató baloldali meggyőződésű értelmiség ellenében. Mert annak számtalan nyoma van a korabeli dokumentumokban, hogy a munkások nemcsak a rákosista, hanem a kapitalista restaurációt is határozottan elutasították.

Másfelől úgy látom, hogy a többpárti szabad választások követelése nem feltétlenül azonos a polgári demokrácia, mint a kapitalista piacgazdaság politikai-hatalmi formája megteremtésének (netán visszaállításának) szándékával. Elméletileg lehetséges többpárti szocializmus (szocialista

\footnotetext{
${ }^{4}$ Biвó 1990a. 159.

5 SzABó 199.293.

${ }^{6}$ RAINer 2002.

7 LOMAX 1989.; RAINER 2002.; SALAMON.

8 Ripp 2002271.

9 GYÁNi 2007. 48.

10 VARga 2006.
} 
vagy munkás demokrácia) akkor is, ha a Kreml csak olyan többpártrendszereket tűrt meg, ahol a legkisebb esély sem volt parlamenti váltógazdálkodásra, a kommunista párt hegemóniája ezekben az országokban hasonlóan teljes volt, mint azokban, ahol csak egyetlen párt létezett. Nagy Imre, a jól képzett marxista snagovi feljegyzéseiben tagadta, hogy a szocialista állam csak és kizárólag egypártrendszerre épülhetne: „A szocializmus nem ismer olyan elvet, amely az egypártrendszert a népi demokrácia vagy a szocializmus ismérvévé mondaná ki, mintha a népi demokrácia csakis egypártrendszer mellett létezhetne". ${ }^{11}$ Nagy szerint tehát létezhetnek és működhetnek különböző politikai pártok a népi demokráciában is, vagyis a polgári demokrácia mellett elméletileg létezhet szocialista vagy munkás demokrácia is. (Ez volt a chilei út lényege: felépíteni a szocialista társadalmat a demokrácia, a pluralizmus és a szabadság alapelvei szerint. ${ }^{12}$ )

Abból pedig, hogy ötvenhat alapvető és általános követelése a demokratikus pártok müködésének visszaállítására irányult, nem következtethető több, mint hogy a szovjet típusú egypárti zsarnokság ellen fellépők a diktatúra ellen fontos biztosítéknak látták politikai pártok szabad működését: „a többpártrendszer úgy jelent meg és joggal, mint a szabad politikai élet jelképe és biztosítéka" ${ }^{13}$ Hogy a szovjet típusú egypárti diktatúránál jobbnak látták a pluralista képviseleti demokrácia Nyugaton bevált formáját. A programalkotás idején mást nem is állíthattak szembe azzal, amit elutasítottak: nem volt más ismert alternatíva. Ráadásul az egyetemi gyűléseken felszólalók nem akartak forradalmat csinálni. Ök csak azoknak a reformoknak a következetes folytatását akarták, amelyeket 1953-ban a Nagy Imre vezette kormány indított el, amelyeket ezért Nagy Imre neve fémjelzett, de amely demokratizálás elől a Rákosi helyébe lépő Gerő sem zárkózott el, sőt, noha kétségtelenül kevesebb hitellel, mint Nagy Imre tette, maga is a rendszer demokratikus reformját hirdette. ${ }^{14}$ A pártok működésének követeléséből tehát nem vonható le több következtetés, mint hogy a diákok (és az október 23-án melléjük kiállók, ahogy este a Kossuth téren magukat definiálták: egész Budapest, a nemzet ${ }^{15}$ ) elutasították az egypárti diktatúrát, demokratikus ellenőrzés alá akarták vonni a politikai hatalmat, és ilyen kontroll szerepre alkalmasnak látták a pártokat. De már október 23. elött sem elégedtek meg azzal, hogy kizárólag pártok gyakoroljanak ellenőrzést a politikai hatalom felett. Teljes vélemény-, szólás- és sajtószabadságot követeltek, és követelték a nem intézményesült nyilvánosság ellenőrzési jogának biztosítását: nyilvános tárgyalást Farkas Mihály és társai bünügyében, a külkereskedelmi szerzödések nyilvánosságra hozatalát. A diákok nemcsak az egypárti diktatúrát utasították el, hanem az azt különösen jellemző titkosságot, zártságot, a kamarillapolitikát. Erre érzett rá a Szabad Nép vezércikkírója, amikor kiemelte: „Az egyetemi ifjúság széles nyilvánosság [kiemelés tőlem - Sz. A.] előtt adott hangot politikai állásfoglalásának." ${ }^{16}$ Ezek szerint már a programalkotási szakaszban kettős ellenőrzés alá akarta vonni a politikai hatalmat a változást akarók tábora. A pártok révén szakszerü, intézményi ellenőrzés, a szólás- és sajtószabadságon keresztül pedig egy nem intézményesült társadalmi ellenőrzés alá - noha az, ami a pontokban helyet kapott, még nem különbözött a nyugati demokráciák hatalomellenőrzési elméletétől és gyakorlatától.

De ötvenhatot nemcsak a pártok szabad müködésének követelése jellemezte, hanem a nyilvánvaló pártellenesség is. ${ }^{17} \mathrm{Ez}$ jellemző volt ötvenhat minden szegmentjére: a diákokra, a

11 Nagy 2006137.

12 Garces 1973. 140.

13 Biвó 1990b. 199.

14 BENCSIK 2009.

15 Litván György személyes közlését idézi: RAINER 1999. 244.

16 Szabad Nép, 1956. október 23. Új, tavaszi seregszemle.

17 Biвó 1990b. 199.; Вiвó 1990c. 207. 
fegyveresekre, a munkástanácsokra egyaránt. Kezdettől rossz szemmel nézték, akadályozták, leplezetlen gúnnyal, sok esetben megvetéssel figyelték szervezkedésüket, amit úgy tekintettek, mint tülekedést a hatalomért. A november 4. előtti pártellenességre (mert most erre az időszakra koncentrálok) két magyarázat létezik. Az egyik szerint generációs ellentét volt a győzelem kiküzdői és a pártoknak a győzelem után megjelenő szervezői között: előbbiek fiatalok voltak, huszonévesek, a pártokat pedig egy idősebb korosztály, a negyvenesek és náluk is idősebbek szervezték. Ezt azonban nem igazolja a források beható elemzésére alapuló kutatás. Az október 28. előtti harcokban részt vevő fegyveres felkelők többségét valóban huszon- és tizenévesnek mutatják az eddigi kutatások, de egyfelől nincs nyoma, hogy ők alapvetően más célokat képviseltek volna, mint a diákok vagy a forradalmi (munkás)tanácsok mögött állók, másfelől az októberi harcok résztvevőiről annyira esetleges információink vannak, amelyek csak nagyon bizonytalan megállapításokra adnak alapot - életkoruk vonatkozásában is. A diákok értelemszerüen húszas éveik elején jártak, ám kezdettől együtt voltak velük oktatóik, méghozzá nem csupán fiatal tanársegédek és adjunktusok, hanem „idősebb” tanárok is (a szegedi professzor, Perbíró József 1908-ban született; az október 25-én Budapesten életét vesztő I. Tóth Zoltán 1911-ben; a Borsod Megyei Munkástanács elnökségébe beválasztott Fekete László 1918-ban). A munkástanácsok esetében pedig számos nyoma van, hogy november 4. után helyet biztosítottak a fiataloknak, ${ }^{18}$ vagyis azt megelőzően jobbára nélkülük működtek a tanácsok, azok tagjai tehát nem voltak fiatalabbak a pártok szervezőinél. A generációs különbség tehát nem indokolhatja a pártok eltérő megítélését.

A másik magyarázat szerint a pártok versengésének megindulását azért törekedtek későbbre halasztani, nehogy az megbontsa a nemzeti egységet a győzelem, vagyis a szovjet csapatok kivonulása előtt, de ez sem tűnik meggyőzőnek. A nemzeti egység két általánosan támogatott követelésre épült: nemzeti függetlenség és demokrácia. Ezekről a számottevő politikai befolyás reményében induló pártoknak nem volt egymástól és a magyar társadalom artikulált akaratától eltérő véleményük, más téren folytatott versengésük tehát nem bonthatta volna meg az ezekre alapuló nemzeti egységet.

A forradalom táborában megmutatkozó pártellenességnek, úgy tűnik, más fontos okai voltak. Ilyennek tekintem a pártok hitelvesztését, hiteldeficitjét, ami általános érvényünek tekinthető: nem csak Magyarországra és nem csak 1956-ra jellemző tendenciának, amit jól mutat napjainkban a pártellenes pártok sikere Spanyolországtól Izlandon és Csehországon át Magyarországig. 1956-ban azonban a pártokkal szembeni bizalmatlanság legfőbb oka az ország 1945 utáni elbolsevizálása volt. Azt a nem kommunista pártok a maguk eszközeivel nem tudták megakadályozni, jóllehet benne voltak a hatalomban: 1946-47-ben kisgazdapárti miniszterelnöke és köztársasági elnöke volt az országnak. De számos kommunista és baloldali csalódott a kommunista pártban is, ami egészen mást hozott, mint amit programjában ígért. A kizsákmányolástól és szükségtől mentes lét helyett a munkásmozgalom 1945-ig elért eredményeinek visszanyesését vagy teljes felszámolását, nagyobb védtelenséget a kizsákmányolással szemben, és nagyobb szegénységet. Az ígért szabadságból pedig csak üres köszönési forma lett. Úgy látom, 1956-ra (vagy talán már korábban) megrendült a társadalom bizalma a pártokban. A nem kommunista pártokban azért, mert nem tudták megakadályozni a diktatúra kiépítését, a kommunista pártban pedig azért, mert kiépítette a diktatúrát. Kézenfekvő volt a következtetés: a pártok a képviseleti demokrácia keretei között képtelenek megvédeni a demokráciát, a jog-

18 PIL, IX. 290. fond 40. ő. e. Lámpagyár, Az ideiglenes munkástanács második ülésének jkv., 1956. október 30. 
államot. Eszerint a műegyetemi programba nem azért került be a pártok szabad müködésének követelése, mert azt jónak, hanem azért, mert az egypárti diktatúránál jobbnak tartották, mert „jobbat eddig még nem találtak fel”. ${ }^{19}$

Másfelől az egypárti diktatúra, amely - hatalmi szempontból kevésbé fontos, ámde látványos pozíciókban - megtartott egy-egy nem kommunista párti politikust, kriptokommunistagyanússá tett minden pártpolitikust, noha 1956-ban nem tudhatták, hogy milyen nagy mértékü volt a kommunista infiltráció a koalíciós pártokba, elsősorban azok vezetésébe. Ha a beépülés mértékével és mélységével a pártok exponensei nem is voltak tisztában, magával a dologgal igen, amely tudás igencsak megnehezítette, hogy az ahhoz szükséges önbizalommal lépjenek a politikai küzdötérre. Arra a küzdötérre, amelyen nem létezett, pontosabban nem müködött a pártpolitizálás hagyományos terepe, a parlament. Amely küzdőtéren a pártok bevett, hagyományos tömegkommunikációs fórumát, a nyomtatott sajtót háttérbe szorította egy annál gyorsabb, spontán nyilvánosság: a plakátoké, a röplapoké és a házak falán, üzletek kirakatain és a különböző jármüveken megjelenő feliratoké - némiképp megelőlegezve a mai közösségi híráramlást. És amely közéleti terepen a pártok megjelenésekor már olyan szereplők voltak jelen, akik közmegelégedéssel látták el a felmerülö feladatokat, köztük az emberek politikai képviseletét - nem, vagy alig hagyva betöltetlen teret a pártok számára.

Mert amikor október 24-én az ország rendkívüli helyzetre és rendkívüli eseményekre ébredt, még sehol sem voltak a pártok. Mert amikor 26-ára nyilvánvalóvá vált, hogy a szovjet csapatok a 23-24-i forgatókönyv alapján nem tudják megoldani a helyzetet, még sehol sem voltak a pártok. Mert amikor 28-án a Nagy Imrétől a rádióba beolvasott kormánynyilatkozatot győzelemnek hallotta a változást akarók tábora, még sehol sem voltak a pártok. Ami az ő színre lépésük előtt, a forradalom első hetében történt, az hatalmas tekintélyt, bizalmat és erőt adott az októberi harcok résztvevőinek

A követelések között sehol sem szerepelt az ország közigazgatásának, a tanácsrendszernek a gyökeres átalakítása, és a munkahelyek közül is kizárólag a termelö üzemek vezetésébe javasolták csak bevonni a dolgozókat. Október 23. után azonban ezen a téren spontán módon váratlan és radikális változások történtek, miután megbénult, majd napok alatt összeomlott minden igazgatási szervezet: a közigazgatás, a munkahelyi irányítás, elsőként és legfontosabbként a kor szakrális helyeinek, a hivatalos ideológia és az alkotmány szerint a hatalmat gyakorló munkásokat tömörítő gyáraknak az irányítása. Mert azokat érték az első támadások, hiszen a Rádió ostroma a gyárak megrohanásával kezdődött, ahonnan fegyvereket lehetett szerezni. Az első felkelők nem akartak mást, csak ami a harchoz kellett: fegyvert és lőszert. Nem szállták meg az üzemeket, amelyekbe sikerült bejutniuk, csak felfegyverkeztek, és visszatértek a Rádióhoz, hogy kifüstöljék onnan az ávósokat. A felkelésnek az első éjszakán még nem volt más célja. Az éjszakai támadásokat követően pedig október 24-én mindenhol megerősítették a gyárőrségeket: legalább az addig rendszeresített kispuskáknál nagyobb tüzerejü fegyverzettel, de a stratégiailag vagy más szempontból fontosabb helyeket hivatásos fegyveres erővel: elvétve a magyar néphadsereg alakulataival, jobbára azonban azoknál megbízhatóbbnak tekintett magyar államvédelmi vagy szovjet egységekkel.

Az eltérő megoldások ugyanazt a következményt vonták maguk után: mindenütt megkezdődött a munkások spontán szerveződése, új, hamarosan munkástanácsnak nevezett szervezetek felállítása. Mert az üzemeket addig irányító hármas, ha a helyén maradt, képtelen volt megoldani

19 Biвó 1990b. 200. 
a felmerült feladatokat. De október 25-étől (24-én kijárási tilalom volt érvényben) közülük egyre kevesebben mentek be az üzemekbe. Volt, akit a fegyveres harc és a közlekedés leállása riasztott vissza. Volt, aki nem akart szembesülni azzal az ellenséges hangulattal, ami a gyárban várta, és nyilván többen voltak, akiket pártfeladatként máshova (leggyakrabban a pártházak védelmére) rendeltek, ahol, fegyverrel, inkább érezték magukat biztonságban, mint a gyárakban. Ott pedig valamire szükség volt, ami felügyeli és ellenőrzi a megnövelt gyárőrséget. Ami képviseli a gyárat, a dolgozókat az oda telepített fegyveres erővel szemben; közremüködik a fegyveresek elhelyezésével, elszállásolásával kapcsolatban óhatatlanul felmerülő feladatok megoldásában; és igyekszik elhárítani a fegyveres erő tekintetében egyenlőtlen felek összeütközését. Ami intézkedni tud a gyár és a dolgozók legszükségesebb ügyeiben. Mert egy termelöüzemben a munka leállását is meg kell szervezni, a leállás nem pusztán azt jelenti, hogy a dolgozók leteszik a kalapácsot. Biztonságos helyre kell elzárni a tüz- vagy robbanásveszélyes eszközöket. Biztosítani kell, hogy a gyárban lévő értékeket, elsősorban a gépeket és a kész- vagy félbehagyott termékeket ne érje kár. Le kell állítani a kazánokat vagy a minimálisan szükséges fütéshez igazítva csökkenteni kell a hőtermelésüket. És a rendkívüli, a történelmi helyzettől függetlenül továbbra is léteztek (sőt megszaporodtak) a mindennapi problémák: gondoskodni kellett arról, akinek megrongálódott a lakása vagy más ok miatt kényszerült azt elhagyni; arról, aki hivatalos ügyben érkezett a gyárba, de a harcok miatt nem tudott hazamenni; arról, aki valamilyen okból képtelenné vált önmagáról gondoskodni. Másfelől pedig szükség volt valamire, ami hangot tud adni a munkások véleményének és akaratának, felvállalja annak képviseletét, és továbbítását a nyilvánosság vagy valamilyen felsőbbnek tekintett fórum elé. Ami az adott kollektívát a munkabeszüntetés sztrájkká emelésével bevonja a nemzeti függetlenségért és a szabadságért folyó harcba, ezzel bizonyítja nemzeti elkötelezettségét, hogy méltó az irányításhoz szükséges bizalomra. Ami feltétlenül szükséges volt ahhoz, hogy fenn tudja tartani a rendet, meg tudja akadályozni az indulatok elszabadulását. Nem a munkástanácsok vonták magukhoz az igazgatói, a szakszervezeti jogkört és a dolgozók politikai képviseletét. Ellenkezőleg. A feladatok megoldásának szüksége hívta életre a munkástanácsokat.

De feltehetően hiába lettek volna a feladatok, nem, vagy nem olyan munkástanácsok alakultak volna, mint amilyenek alakultak, ha 1956 őszének tisztító vihara nem éri el a gyárakat. De a nyomtatott sajtón (elsősorban az Irodalmi Ujságon), a Petőfi Kör vitáin és az országossá terebélyesedő diákmozgalmon keresztül elérte. ${ }^{20}$ Nyilvánvaló, hogy október 6-án a Rajk-temetésre összegyült százezres tömegben nem csak értelmiségiek és hivatalnokok voltak. A Csepel Müvek majdani munkástanácsa elnökének, Nagy Eleknek a visszaemlékezése szerint tőlük körülbelül ezren vettek részt a szertartáson, biztosan ott volt a munkástanács majdani vezetőségének egy másik tagja is. ${ }^{21}$ A gyári értelmiségből, elsősorban a műszakiak közül többen részt vettek a Petőfi Kör ülésein. Nagy Elek nemcsak részt vett, hanem fel is szólalt az október 10-i vitán, tagja lett a körnek, és kezdeményezte csepeli Petőfi Kör alakítását. ${ }^{22}$ A Petőfi Kör vitáin elhangzottak vidékre is eljutottak, ahol azokat tovább vitatták, müszaki értelmiségiek ott is részt vettek a helyi fórumokon, a Petőfi Kör mintájára alakult helyi szervezetek vitáin. Az egyik debreceni gyár majdani munkástanácsának elnöke 1956 nyarán egy szakszervezeti rendezvényen szólalt fel Rákosi ellen, majd részt vett a Kossuth Kör első nyilvános ülésén. ${ }^{23}$ De október 23. előtt már

20 KozÁK-Molnár 1993. Bácsi József visszaemlékezése, 1989. 61.

21 KozÁk-Molnár 1993. Nagy Elek visszaemlékezése, 1986. 16.; Bácsi József visszaemlékezése, 1989. 61.

22 KozÁk-Molnár 1993. Nagy Elek visszaemlékezése, 1986. 15. Nógrád Megyei Levéltár 16.

23 KozÁK-Molnár 1993. Mervó Zoltán visszaemlékezése, 1992. 310. 
a kétkezi dolgozók is igényt formáltak rá, hogy saját kezükbe vegyék ügyeik intézését, beleértve az egész országot lázban tartó kérdéseket. Napokkal a forradalom kitörése elött olyan kérdéseket szegeztek az üzembe meghívott Marosán Györgynek a Kábel- és Sodronykötélgyár dolgozói, amiket a pártvezér a szocialista tábor rágalmazásának, az ellenség hangjának minősített, és azzal fenyegette munkás hallgatóságát, hogy jelentést tesz róluk a Politikai Bizottságnak. ${ }^{24}$ Október 22-én a miskolci DIMÁVAG-ban fiatal mérnökök és közvetlen termelésirányítók kezdeményezték munkás nagygyűlés összehívását a feltornyosult gondok megvitatása, megoldása érdekében. Ehhez „kezdtek aláírásokat gyüjteni a dolgozók között olyan sikerrel, hogy az első kibocsátott ívek szinte azonnal vissza is tértek hozzájuk, nevekkel sűrün teleírva." ${ }^{25}$ A budapesti Lámpagyárban (amely nevével ellentétben fontos fegyvergyártó üzem volt), október 23-án jelent meg a faliújságon egy azonnali változásokat követelő szöveg. ${ }^{26}$

Munkástanácsok alakítása azért is volt kézenfekvő, mert a rendszernek az önigazgatás bizonyos formáin keresztül megvalósuló demokratizálása már a forradalom kitörése előtt a közbeszéd tárgya volt. Nemcsak a szakszervezet tanulmányozta a jugoszláv munkástanácsokat, de az őszi diákmozgalomnak is fontos követelése volt például a diákotthonok önkormányzattal rendelkező kollégiummá emelése. Nem előzmények nélkül került az írók október 23-i kiáltványába a követelés, hogy „Az üzemeket a munkások és a szakemberek vezessék.” ${ }^{27}$ Megalakításuk nemhogy ellenkezett, de összhangban volt az Alkotmánnyal, amely kimondta: „A Magyar Népköztársaság a munkások és dolgozó parasztok állama. A Magyar Népköztársaságban minden hatalom a dolgozó népé. [...] A Magyar Népköztársaság feladatainak ellátásában az öntudatos dolgozók szervezeteire támaszkodik." ${ }^{28}$ A fordulat éve óta a munkások hatalmáról szónokoltak a hatalom valódi birtokosai, azt hirdette a hivatalos propaganda: „nem szorulnak magyarázatra az ipari munkásság elévülhetetlen érdemei, amelyekkel a felszabadulás óta eltelt száz és száz alkalommal beigazolta, hogy Pártunkkal az élén kiérdemli a vezetést.” ${ }^{29}$ A „szocializmus által felfokozott munkásöntudat”, ami nélkül Garton Ash szerint nem lett volna a gdanski hajógyári munkások 1970. decemberi megmozdulása, ${ }^{30}$ nyilván ott munkált ötvenhatos magyar kartársaikban is. Ha le is lepleződött előttük a rendszer hazug volta, a maguk politikaformáló szerepét, sőt, történelmi küldetését mégis elhitték. És ez „az óriás, akit maga a szocialista rendszer teremtett” nem a huszonharmadika előtti rend védelmében lépett sorompóba, ahogy a hatalmat addig birtoklók remélték. Maga is mást akart, mint ami addig volt, így a változásért küzdők mellé került.

Több helyen a hatalmat addig birtokló vezetők kezdeményezték valamilyen új szerv alakítását abban a hitben, hogy annak segítségével a munkásokat szembe tudják fordítani az ellenforradalommal. Október 26-án Újpesten már kerületi munkástanácsot szerveztek, amely jelentősebb fegyveres erő felett rendelkezett. ${ }^{31}$ A Ganzban a funkcionáriusok a munkások távollétében magukat deklarálták munkástanácsnak, de kénytelenek voltak meghátrálni a dolgozók elől: a 27-én újjáalakított munkástanácsba egyikőjük sem került be, sőt, mindannyiukat eltávolították

24 Szakolczai 2006. A Kábel- és Sodronykötélgyár munkásainak kérdései Marosán Györgyhöz, 1956. október 18. 79-80.; Marosán György válasza a Kábel- és Sodronykötélgyár munkásainak, 1956. október 18. 81-83.

25 Szakolczai 2003. 130

26 ÁBTL, V-150361/1. 1956-os Monográfia. Jelentés a Lámpagyárban működő munkástanácsok tevékenységéről, 1959. augusztus 8. 183.

27 Szakolczai 2001. 130. A Magyar Írók Kiáltványa, 1956. október 23.

28 BALogh 1986. 123., 132. A Magyar Népköztársaság alkotmánya.

29 BALogh 1986. 63. Rákosi Mátyás beszámolója az MDP KV 1949. május 31-i ülésén.

30 AsH 1990. 21. A következő idézet is innen.

31 PIL, 1956-os gyűjtemény, 19. ő. e. Sándor újpesti PB-titkár jelentése a pártközpontnak, 1956. október 26. 
a gyárból. ${ }^{32}$ Akár ellenállással, akár együttműködéssel próbálkozott, ugyanaz lett a sorsa: az addig vezetö hármas (párttitkár, igazgató, szakszervezeti bizalmi) mindenhol megbukott, csak alig néhányan tudtak - a korábban mutatott szakmai vagy emberi érdemeik alapján kivívott személyes bizalom alapján - valamilyen formában benne maradni az új vezetőségben. Természetes, hogy az egypárti diktatúra elleni felkelés megfosztotta hatalmuktól a párt munkahelyi exponenseit. Hozzá nem értésük, képzetlenségük, és/vagy basáskodó magatartásuk miatt valamilyen formában eltávolították az igazgatókat (és azokat a középkádereket, akik ellen súlyos kifogások merültek fel): általában szabadságolták vagy felfüggesztették őket a munkavégzés alól, amíg ügyükben nem születik döntés, de általában ügyeltek arra, hogy „kenyértelenül senki nem maradhat". ${ }^{33}$ Rosszabb esetben elkergették őket. És hivatalát vesztettnek tekintették a szakszervezeti bizalmikat, mivel nem a dolgozók választották meg, hanem felülröl nevezték ki őket.

Általában akkor jön létre valami új, ha az addig használatban volt már nem alkalmas a célra. A munkástanácsokban testet öltő alternatív munkásmozgalom talán legfőbb teoretikusa, Anton Pannekoek abban látta a munkástanácsok létrejöttét eredményező szükséghelyzetet, hogy a munkásmozgalom hagyományos szervezetei, a szociáldemokrata párt és a szakszervezet az első világháború idején, sőt részben már előtte, elszakadtak választóiktól, eltértek a rájuk rótt feladatoktól: a kapitalizmus megdöntése helyett annak megszelídítésére törekedtek. Ezzel elvesztették a dolgozók bizalmát, akik új formát kerestek és találtak, hogy megpróbálják elérni céljukat. ${ }^{34} \mathrm{Ha}$ megállapításai érvényesek a német szociáldemokráciára és a német szakszervezeti mozgalomra, akkor még inkább érvényesek 1956 szovjetizált Magyarországára, ahol a harc éppen az egypárt diktatúrája ellen folyt, azt tehát nem vezethette a csak nevében dolgozók pártja vagy az annak kiszolgálására kényszerített szakszervezet. Ezért született új szervezet: a munkástanács.

Október 26-ától - amikor hirtelen mindenhol feltüntek - a munkástanácsok hármas legitimitást élveztek. Az MDP KV nyilatkozata és a SZOT felhívásai a hivatalosság részéröl biztosították törvényességüket. Előbbi kinyilvánította, hogy „helyesnek tartja az üzemi munkástanácsok választását”, ${ }^{35}$ egyben megpróbálta azokat a szakszervezeten keresztül ellenőrzése alá vonni. Befolyása maradékának megőrzése érdekében támogatta a szakszervezet „munkás-ifjúsági” szervezet alakítását. ${ }^{36}$ Esti felhívásában igyekezett részletesen szabályozni a munkástanácsok megalakításának módját és a szervezet jogait - inkább a rend helyreállítása, a munka felvétele érdekében, mint a munkások követelésének valóra váltásáért. ${ }^{37}$ És a munkástanácsok megalakítása összhangban volt azokkal az ötletelésekkel, amelyeket 1956 nyarától hallottak és olvastak önigazgatásról, munkás-önigazgatásról, a tanulmányozandó jugoszláv modellről. ${ }^{38}$ Másfelől a dolgozók, munkatársaik bizalma, a lehetőséghez képest demokratikus megválasztásuk alulról legitimálta létüket. A választások általában titkosak voltak, a munkások a szavazás előtt összeállított jelöltlista alapján választhattak, és ügyeltek arra is, hogy mivel az első választás idején nem volt ott mindenki, ezeket a testületeket eleve ideiglenesnek tekintették, kijelentve, hogy a

32 KozÁK-Molnár 1993. 80. Lukách Tamás visszaemlékezése, 1992.

33 Csomor - Kapiller 1996. 157. A Zalaegerszegi Pedagógus Bizottság Elnökségétől távmondat a Járási Pedagógus Bizottsághoz, 1956. október 30.

34 PANNEKoEK 1947.

35 SzakolCZai 2006. 147. Az MDP KV nyilatkozata, 1956. október 26.

36 Szakolczai 2001. 158. A SZOT kibontakozási javaslata, 1956. október 26.; VARGA 1989. 83-84.

37 VARGA 1989. 86. Kossuth rádió, 1956. október 26.

38 BerÁnNÉ Nemes - KAJÁRI 1989. 300-311. A SZOT Elnökségének javaslata az üzemi szakszervezeti szervek önállóságának, hatáskörének növelésére, a munkásellenőrzés gyakorlati megvalósítására, 1956. augusztus 24. 
végleges tanácsot akkor fogják megalakítani, amikor már a dolgozók többsége bent lesz a munkahelyen. Legfontosabbként pedig: létüknek és müködésüknek erős, forradalmi legitimációt adott, hogy összhangban tudták magukat a változásért más formában vagy más szervezetben küzdőkkel, és tudatában voltak annak, hogy ezt a küzdelmet nagy szimpátiával, ahogy ők látták: csodálattal figyeli a nagyvilág.

A munkástanácsok három feladatnak igyekeztek megfelelni. Irányították a gyárat, mint az üzem gazdái. Ellátták a dolgozók politikai képviseletét, mint a munkások forradalmi, harci szervezete. És a szakszervezet helyébe lépve betöltöttek érdekvédelmi feladatokat. De miközben nem törekedtek a szakszervezet megszüntetésére (feladatait csak ideiglenesen, az üzemi bizottságok demokratikus megválasztásáig vették át), ragaszkodtak a dolgozók politikai képviseletéhez helyi és országos szinten, és ahhoz, hogy ők a gyár gazdái, irányítói. ${ }^{39}$

A munkás-önigazgatásnak a munkástanácsokon keresztül történő megvalósításával az 1945 után államosított üzemek állami tulajdonból társadalmi tulajdonba kerültek: „Ez betetőzése a gyárak népi tulajdonba vételének." ${ }^{40}$ Az irányítást a felülről kinevezett és kizárólag felfelé felelős igazgatótól (illetve a párt- és a szakszervezeti vezetőtől) a közvetlenül a munkások által választott és közvetlenül nekik felelős munkástanácsok vették át. A munkás-önigazgatást úgy értelmezték, hogy az üzemi kollektíva készíti el a termelési tervet, dönt a termeléssel kapcsolatos általános kérdésekről, rendelkezik az adózás utáni nyereséggel: a munkások irányítják a termelést. (A termelés irányításának saját kézbe vételét Pannekoek fontosabbnak tartotta, mint a tőkés megfosztását a profittól. ${ }^{41}$ ) A munkástanácsok révén tehát társadalmi tulajdonná vált az addigi állami tulajdon, és demokratikussá az addig hierarchikus termelésirányítás. Ez pedig forradalmi jelentőségű változás, bárha visszatérés az 1917. október előtti Oroszország autonóm munkásmozgalmához. Amikor az üzemi tanácsokba szerveződött munkások azért támogatták a bolsevik hatalomátvételt, hogy a hatalomra segített párt betetőzze azt a folyamatot, amelynek révén kezdetben ellenőrzési jogokhoz jutottak, ami a későbbiekben az irányításban való részvétellé (participációvá) szélesedett. Hogy végre a gyár igazi gazdáivá válhassanak, megteremtve egy autentikusan demokratikus társadalmat. ${ }^{42}$ (Ami helyett egy autoriter, antidemokratikus állam létrejöttét segítették.)

Az ötvenhatos munkástanácsok vállalatirányítási tevékenységének szisztematikus feltárásával még adós a történettudomány. Ennek több oka lehet. Magyarázhatja, hogy a hidegháborúra koncentráló politikatörténeti kutatások számára a kérdésnek nem volt különösebb jelentősége. És magyarázhatja, hogy a föként forrásként használt peres iratokban alig van nyoma, hiszen, ahogy azt Takács Tibor megfogalmazta: a perekből csak a bűncselekmények valósága írható meg, nem a történeti valóság, ${ }^{43}$ márpedig a vállalatvezetésbe való beleszólást a bűnüldöző szervek láthatóan nem tekintették büntetőjogi eszközökkel üldözendő cselekménynek, különös tekintettel arra, hogy e téren 1957 tavaszáig megmaradtak a munkástanácsok - jóllehet megnyirbált - jogai. Nem illett az ellenforradalmi szervezkedés sablonjába, hogy munkások, mérnökök és termelésirányítók saját kezükbe veszik egy-egy üzem irányítását. Ennek pedig az lett a sajnálatos következménye, hogy a forradalom idejéből viszonylag kevés munkástanácsi dokumentum maradt meg, leginkább azok, amelyek alkalmasnak látszottak egy-egy vádlott bűncselekményének

39 BFL, XXV.4.f. 7104/1957. Nagy Elek és társai pere. Nagy Elek egyéni feljegyzései, 1957. január 17.

40 VARGA 1989. Kossuth Rádió, 1956. október 27.

41 Pannekoek 1947.

42 Mandel 2011. 117-119.

43 TAKÁCS 2010. 
bizonyítására. A perekben fel nem használt (és így az államvédelmi és a bírósági irattárakban nem megőrzött) iratok zöme vélhetően elkallódott, bár szisztematikus kutatással nyilván többet fel lehetne tárni a különböző vállalatok levéltárba került irattömegéből.

Az azonban az eddigi kutatások alapján is jól kirajzolódik, hogy a munkástanácsok nagyon komolyan vették ezt a szerepkört. Általában a személyi kérdések álltak az első helyen. Nem azért, amivel a megtorlás idején vádolták őket, hogy üldözték az elvhű kommunistákat (ahogy akkor nevezték a rákosista kádereket), hanem éppen ellenkezőleg, az ő védelmükben: a hivatalos eljárással akarták elejét venni a személyes leszámolásnak, önbíráskodásnak. A győri vagongyárban is elbocsátották vagy felfüggesztették azokat, akik szaktudásával vagy emberi magatartásával szemben kifogások merültek fel, mindenekelőtt azokat, akiket az ávó besúgóinak tartottak. November 4. előtt és után is felmondtak az igazgatónak, kinyilvánítva ezzel, hogy a munkástanács a gyár legfontosabb szervezete, fölötte áll az igazgatónak, közvetlen felettese a minisztérium. A vagongyári munkástanács már megalakulásakor magához vonta az irányítási jogokat: „A munkástanács irányítja a vállalatot a távlati tervek, a műszaki fejlesztési tervek elkészítésében, a belső költségvetések elkészítésében, a vállalat üzleti tevékenységében." 44 Tanácskoztak az export átstrukturálásáról, a csak importból beszerezhető alapanyagok biztosításáról, a feleslegesnek tartott szervezeti egységek megszüntetéséről, az ötvenes években Csepelhez csatolt csavargyár visszafogadásáról, és megszabadították a gyár nevét a német kommunistától Wilhelm Piecktől.

Mivel a munkástanácsok kezdettől az üzem irányítójának tekintették magukat, okafogyottá vált a hagyományosan legfőbb szakszervezeti feladat, a bérharc, a munkástanács, mint érdekvédelmi szerv nem követelhetett béremelést a munkástanácstól, mint az üzem irányítójától. A klaszszikus szakszervezeti feladatok közül azonban többet felvállaltak. A győri vagongyár munkástanácsa - értelemszerűen már november 4. után - például intézkedett arról, hogy a kisgyermekes anyák, akiknek a férjük is dolgozik (vagyis lényegében az összes), igazoltan otthon maradhattak, mivel a gyár bölcsődéje nem üzemelt. Lakásbizottságot állítottak fel, hogy biztosítsák a szükséghelyen vagy egészségtelen körülmények között élők lakáshoz jutását. Felvállalták a dolgozók kislakás-építésének segítését, amit addig a szakszervezet koordinált. Nagyrészt azonban olyan kérdésekkel foglalkoztak, amelyek a Kádár-kori szakszervezet jellegzetes feladatai lesznek majd: a dolgozók munkaruhájának biztosítása, üdültetés vagy kulturális programok szervezése stb.

Nehéz a szakszervezeti, érdekvédelmi feladatoktól megkülönböztetni a dolgozók mindennapi problémái megoldásának a segítését. Ide tartozik a törekvés, hogy biztosítsák számukra mindazon javakat, amelyek a mindennapokhoz szükségesek. A vagongyári munkástanács közreműködött a november 4. után elszabaduló piaci élelmiszerárak és a feketepiac megfékezésében; hogy biztosítva legyenek az alapvető közszükségleti cikkek: a kenyér, a krumpli, a téli tüzelő. (Fentieken túl még a cigaretta biztosítását tekintették fontosnak.) Bevezetni javasolták a kereskedelemben a déli sziesztát, hogy délután akkor is nyitva legyenek a boltok, amikor a munkások haza indulnak. Hogy az ilyen kérdéseket mennyire (és joggal) fontosnak tekintették, azt mi sem mutatja jobban, mint hogy erről november 5 -én is tárgyaltak. ${ }^{45}$ Talán a leginkább ez jelzi, hogy a munkástanács mennyire nem idegenedett, nem távolodott el a dolgozók valós problémáitól. A nagy gazdasági és politikai ügyek nem vonták el figyelmét a mindennapok kevéssé látványos kérdéseitől.

A munkástanácsok három különböző, de egymással összefüggő szinten politizáltak, kap-

44 Szakolczai 2007. 62. A vagongyári, hajtómügyári és csavargyári munkásság szolidaritást vállal Budapest népével.

45 Szakolczai 2007. 97-98. Feljegyzés a vagongyári munkástanács részleges üléséről, 1956. november 5. 
csolódtak be a rendszer demokratizálásáért indított küzdelembe, ami jelentős részben éppen az ő megjelenésük és tevékenységük révén vált forradalommá. Részt vettek helyi szinten az új, forradalmi hatalom kiépítésében és annak működtetésében. Győrött is a gyárak küldötteinek kezdeményezésére alakult meg a forradalmi szerv, a Győri Nemzeti Tanács (GYNT). ${ }^{46} \mathrm{Az}$ ő segítségükkel sikerült robbanásveszélyes helyzeteket megoldani: a megyei rendőrkapitányság elfoglalása után (a honvédséggel együttmüködve) munkásküldöttek akadályozták meg a fegyverek széthordását és a leszámolást az ávósokkal. Nagyrészt az ő segítségükkel sikerült semlegesíteni Somogyvári Lajos ellenkormányt alakítani akaró puccskísérletét. A GYNT-be a vagongyár hét föt delegált. Ezzel egyfelől erősítették a győri forradalom vezetőségét (azt megtámogatták a vagongyár társadalmi és politikai súlyával), másfelöl biztosították, hogy a városházán ne születhessen olyan döntés, amellyel a vagongyári (általában a győri) dolgozók nem értenek egyet. A GYNT vezetői közül senkinek sem voltak ellen-forradalmi, vagyis a munkáshatalom elleni tervei, de érthető a munkástanács gyanakvása: a városban többször elterjedt az utóbb mindig hamisnak bizonyult hír, hogy a városházán úri restaurációra készülnek. Nincs nyoma, hogy alapvető kérdésekben ellentét lett volna a GYNT vezetői és a munkások képviselői között, de annak igen, hogy érdemi vitákat folytattak, például a Nagy Imre-kormány elismeréséről vagy a munka felvételéről.

A munkástanácsok politikai tevékenységének másik szintje a központi hatalommal folytatott küzdelmük volt. Október 26-án Győrött hatfös küldöttséget alakítottak, hogy juttassa el a követeléseket a kormányhoz: abba a tanács és a pártbizottság egy-egy funkcionáriusa mellé négy munkásküldött került be. Október 29-én a vagongyári munkástanács indított küldöttséget a kormányhoz, amelyet másnap fogadott Nagy Imre. Legfőbb követelésük a gazdasági csődért felelősnek tartott miniszterek leváltása volt, annak alátámasztására még november 2-án is az egész Dunántúlra kiterjedő sztrájkot helyeztek kilátásba. A politizálás harmadik szintjének, formájának tekintem a kapcsolatok felvételét (inkább a meglévő gazdasági kapcsolatok megfejelését) győri, valamint távolabbi üzemek munkástanácsaival. Ezek elsődleges célja a tájékozódás volt, hiszen a bizalmatlanul fogadott rádió- és sajtóhíreknél hitelesebb volt a küldöttek személyes tapasztalaton alapuló beszámolója. A tájékozódás és a tájékoztatás pedig nem korlátozódott a gyáron kívüli (helyi és országos) politikai eseményekre, hanem beletartozott a munkástanács szervezeti struktúrája, tevékenysége és természetesen a követelései. A vagongyári munkástanács már megalakulása napján tárgyalt győri üzemek, illetve a Szőnyi Kőolajipari Vállalat munkástanácsának küldöttségeivel. De még november 4. elött kapcsolatba kerültek olyan gazdaságilag és politikailag jelentős üzemekkel, mint a Csepel Művek, a DIMÁVAG és a Lenin Kohászati Müvek, amelyek társadalmi súlya, presztízse október 23. előtt is nagy volt, a forradalomban vitt szerepük pedig azt még tovább növelte.

A vagongyár munkástanácsa, a térség legnagyobb ipari üzeme két helyet kapott az október 30-án alakult Dunántúli Nemzeti Tanácsban, november 11-étől pedig a megyei és a városi tanács végrehajtó bizottságában is ott voltak küldöttei. Sőt, november közepén egyikük a városi tanács elnöke, egy másik pedig december elején a megyei elnökhelyettese lett. A hagyományosan nagyobb szerepet betöltő megyei tanácsot - hozzávetőleg a forradalom végéig, vagyis december közepéig - a munkásküldöttek irányították, együttműködve a megyei tanácson alakult munkástanáccsal. Mert nem csak a termelö üzemekben alakultak munkástanácsok. De míg a munkástanácsok november 4. előtti tevékenysége is nagyon aluldokumentált és kevéssé kutatott, ez hatványozottan igaz a különböző elnevezésű munkahelyi forradalmi tanácsokra. Célzott

${ }^{46}$ Szakolczai 2006b. 161-162. 
kutatás híján csak véletlen nyomok vannak, de azokból úgy tűnik: még november 4. előtt lényegében minden munkahelyen forradalmi tanácsok vették át az irányítást, vagy váltak tanácsadó testületként az igazgatóval egyenlő jogú vezetővé. Forradalmi tanácsok vették át a minisztériumok irányítását. Forradalmi tanácsok alakultak az igazságszolgáltatásban a járásbíróságoktól a Legfelsőbb Bíróságig. Forradalmi vezetőséget választottak az ügyvédi kamarák. Forradalmi tanács alakult a Szakszervezeti Társadalombiztosítási Központ budapesti területi bizottságán. ${ }^{47}$ Forradalmi tanács alakult az akadémia történettudományi intézetében. Forradalmi tanácsok alakultak az iskolákban és más nevelési intézményekben (például a zalacsányi fiúnevelő otthonban ${ }^{48}$ ), illetve megalakultak az ezeket összefogó járási, városi és megyei oktatási tanácsok és/vagy pedagógus forradalmi tanácsok. Forradalmi tanács alakult Zalaegerszegen a megyei villanyszerelési vállalatnál, a vendéglátó-ipari vállalatnál és az Országos Takarékpénztárnál. ${ }^{49}$ Forradalmi tanácsot alakítottak Vácott a kisiparosok, a tűzoltók és a zenészek. ${ }^{50}$ Forradalmi tanácsok alakultak a kórházakban. Általában munkástanácsnak nevezett testületek alakultak a járási, városi és megyei tanácsokon az apparátus irányítására.

Ezek egy része azért alakult meg, mert az ott dolgozók közül többen egyetértettek az október 23-i követelésekkel, és a maguk módján és eszközeivel, a maguk területén csatlakozni akartak a harchoz: el akarták távolítani a bűnös, rákosista vezetőket, le akartak számolni a múlt hibáival, olyanná akarták tenni munkahelyüket, hogy az képes és alkalmas legyen ellátni feladatát. És mindenekelőtt ki akartak állni a harcot folytatók mellett: amnesztiát, tüzszünetet, a szovjet csapatok kivonását, függetlenséget, szabadságot, demokráciát követelve. A megalakulás másik fontos motivációja a munkahely védelme volt. Felkelés idején szükséges volt, hogy olyan grémium álljon az élén, amely képes és tud tárgyalni ilyen vagy olyan küldöttségekkel. Amely alappal hivatkozhat a maga forradalmiságára. A Legfőbb Ügyészségről például nemcsak azért kellett eltávolítani Non Györgyöt, mert október 23. után szorgalmazta az „ellenforradalom” elleni harcot, a statárium alkalmazását, hanem azért is, hogy őt keresve felkelők ne hatoljanak be az épületbe, és ne dúlják fel azt. Ezek a munkahelyi forradalmi tanácsok a lényeget illetően megegyeztek a munkástanácsokkal: ugyanazt a hármas feladatot vállalták fel, és látták el. Egyszerre voltak a munkahely irányítói (noha nem követeltek maguknak tulajdonosi jogokat, mint a munkástanácsok), az ott dolgozók érdekképviseleti szerve és politikai, harci szervezete. A munkavégzés hagyományosan hierarchikus, irányítókra és irányítottakra tagolt világát napok alatt felváltotta a dolgozók autonóm önigazgatásának demokratikus rendszere.

Jelenlegi ismereteink szerint úgy tűnik, hogy elsősorban Budapesten kívül a munkahelyi forradalmi tanácsok alakulásának legfőbb motorja maga a helyi közigazgatást átvevő forradalmi szerv megalakítása volt. Miután a tanácsokat elsöpörték vagy megbénították a tüntetések, vagy maga az október 28-i fordulat, a nagyobb települések (valamint a járások és a megyék) irányítására, a folyó és a rendkívüli ügyek vitelére szükségessé vált egy új szerv létrehozása. A falvakban ezeket az október-27-28-i nagygyülések, tüntetések után rögtön, közvetlen, nyílt szavazással állították fel, ez azonban egy városban nem volt lehetséges, hiszen az emberek nem ismerték egymást. Ezeken a helyeken tehát a forradalmi testület megalakítását meg kellett előznie olyan küldöttek megválasztásának, akik aztán meg tudják megalakítani saját soraikból a forradalmi tanácsot. A pártok még nem müködtek, és a pártok általi jelöltállítás amúgy is olyan

${ }^{47}$ BFL, XXV.4.f. 9213/1961. Pásztor Géza pere.

${ }^{48}$ MNL-ZML, XXV.1.b. 485/1957. Csaba Antal és társa pere.

${ }^{49}$ MNL-ZML, XXV.1.b. A Zala Megyei Bíróság büntető iratai.

50 Böőr-Gyarmati-Horváth M. 2006. 
hosszadalmas lett volna, amilyenre október utolsó napjaiban nem volt idő. A Hazafias Népfront helyi szervezetei ugyan 1956 őszén kezdtek magukhoz és visszatérni a közéletbe, de sem olyan társadalmi beágyazódottságuk, sem olyan tekintélyük nem volt, ami alkalmassá tette volna őket jelöltállításra (noha ez néhány területen mégis megtörtént). Ebben a vákuumban értelemszerüen azoknak a közösségeknek kellett küldötteket választaniuk, amelyek tagjai a leginkább ismerték egymást, vagyis a munkahelyeknek. (Ha egy kistelepüléseken választás volt, ott utcák szerint választottak küldötteket.) Ilyen küldöttgyülések alakították meg a területi forradalmi tanácsokat. Ahol valamilyen rendkívüli ok miatt a küldöttek megválasztása előtt szükségessé vált a forradalmi tanács megalakítása, ott a következő napokban vagy kiegészítették az első, ideiglenes forradalmi tanácsot, vagy teljesen újat alakítottak. De a területi forradalmi tanács megválasztásának tipikus ötvenhatos formája az volt, amikor a munkahelyeken megválasztott küldöttek alakították azt meg. Így történt Baján, Békéscsabán, Gyöngyösön Szolnokon stb. A területi forradalmi tanácsok közül talán a legjobban feltárt (és a Kádár-korban a legjobban összekuszált) a Borsod Megyei Munkástanács megalakítása. ${ }^{51}$ Miskolcon már október 24-én egymásra talált a forradalom táborának négy legfontosabb komponense: a diákok, a munkások, a kommunista reformerek és az őket támogatni hajlandó fegyveres erő. Együttmüködésüknek köszönhetően sikerült aznap több robbanással fenyegető helyzetet megoldani. Október 25-én azonban már sehogy sem lehetett megakadályozni a diósgyőri nagyüzemek dolgozóinak kivonulását, amit az államvédelmi erőkkel (vagy a városon átvonuló szovjet csapatokkal) való összeütközés elkerülése érdekében kivittek a város szélén lévő Egyetemvárosba. Ott azonban a sokaság már nem érte be szavalatokkal és beszédekkel: eredményt akart, elsősorban a sztrájk meghirdetését, hogy azzal támogassák a Budapesten fegyverrel harcolókat. Hogy a felmerült legfontosabb kérdésekben határozni tudjanak, a tüntetők munkahelyek szerint két-két küldöttet választottak. Ök a sztrájkról hozott határozat után is együtt maradtak, kezdetben sztrájkbizottságnak, délután már ideiglenes megyei munkástanácsnak nevezték magukat. Október 29-ére pedig összehívták a megyei munkástanácsot megválasztani hivatott küldöttgyülést, egyben felszólították a munkahelyeket, hogy addig válasszák meg delegáltjaikat. Az október 26-27-i véres és tragikus események következtében a megyei munkástanács érdemben már október 27-28-án megalakult, de az egyeztető tárgyalásokon kialakult grémium az október 29-i küldöttgyüléstől nyerte el a felhatalmazást.

A területi forradalmi tanácsok megválasztásával egy sajátos struktúra épült ki. A választáson minden dolgozó részt vehetett, noha természetesen csak azok tudtak választani, akik bent voltak (bár sokszor távollévőket is beválasztottak a forradalmi tanácsba). Nagyobb létszámú munkahelyeken többlépcsős volt a választás: az egyes mühelyek (irodák, osztályok stb.) megválasztották saját küldötteiket, akik aztán maguk közül megválasztották azokat, akiket a területi forradalmi tanács megválasztására delegáltak. Ezeken a helyeken a választásra delegáltak alkották az adott munkahely gyakran munkástanácsnak nevezett forradalmi tanácsát, amely a maga kebeléből választotta meg tisztviselőit: általában elnököt, elnökhelyettest és az adminisztrációért felelös titkárt. A területi forradalmi tanácsba delegáltak pedig a területi forradalmi tanács tágabb testületének a tagjai maradtak.

Ezek a területi forradalmi tanácsok sok szempontból hasonlítanak a képviseleti demokráciák önkormányzataira, de néhány nagyon fontos dologban különböznek is azoktól. A legföbb hasonlóság a helyi ügyek intézése, de a forradalmi tanácsok többsége jóval tágabb hatáskört vindikált magának, mint ami egy képviseleti demokráciában, legyen az bármennyire is ke-

51 SzakolcZai 2000, SzakolcZai 2003. 
véssé központosított, megilleti a helyhatóságokat. Szigethy Attila például már október 26-án feloszlottnak nyilvánította Györ-Sopron megyében az államvédelmet, fennhatósága alá vonta a határvédelmet és a határon való ki- és belépés engedélyezésének a jogát. Ezt még indokolhatta a rendkívüli helyzet: az államvédelem azonnali leszerelésének, a határ ellenőrzött megnyitásának a szükségessége, de számos egyéb intézkedés jelzi, hogy a területi forradalmi szervek az általánosan bevettnél sokkal szélesebb jogkört gyakoroltak. A balassagyarmati forradalmi tanács például november 2 -án a város és a járás területére érvényesen módosította (szigorította) a terhesség-megszakításról hozott minisztertanácsi és miniszteri rendeleteket, ${ }^{52}$ amit nyilván nem a rendkívüli, forradalmi helyzet tett szükségessé.

A másik fontos különbség, hogy a területi forradalmi tanácsok fennhatósága alá kerültek a fegyveres erők. Ezt magyarázhatja, hogy ez a megoldás mindkét fél számára előnyös volt: a fegyveres testületek így és ezért kevésbé voltak támadásoknak kitéve, a forradalmi tanács legitimálta működésüket. A forradalmi tanács pedig közvetlen rendelkezést nyert a fegyveres erő felett, amire szüksége is volt olyan időben, amikor rejtőzködő és menekülő ávósok, valamint börtönökből szökött fegyencek garázdálkodásairól terjedtek - utóbb kevés kivétellel valótlannak bizonyuló - rémhírek. A november 4-i szovjet katonai támadás következtében csak találgatni lehet, hogyan alakult volna a forradalom konszolidációja után a fegyveres testületek feletti fennhatóság, az azonban valószínütlennek látszik, hogy a területi forradalmi tanácsok teljes mértékben átengedték volna az azok feletti rendelkezést a központi hatalomnak. Erre mutat, hogy a forradalmi tanácsok a (tágan értelmezett) helyi ügyek intézésén túl még egy feladatot felvállaltak: a lakosság politikai képviseletét, azzal együtt a központi hatalom ellenőrzését, szükség esetén nyomás alá helyezését. Október 28-án a GYNT ultimátumot adott Nagy Imrének a harcok aznap történő befejezésére, megfenyegetve a miniszterelnököt, hogy különben „Dunántúl lakossága a budapesti szabadságharcosok segítségére siet”. ${ }^{33}$ Más tanácsok a kormány azonnali átalakítását, a rákosista miniszterek leváltását, Magyarország ENSZ-képviselöjének a hazarendelését stb. követelték. Ez arra mutat, hogy miként a munkahelyi forradalmi tanácsok kettős feladatot vállaltak fel, hasonlóan cselekedtek a területi forradalmi tanácsok is: az adott terület irányításán túl ellenőrzést akartak gyakorolni a központi hatalom és a fegyveres testületek fölött. Miként az 1918-1919-es német forradalom tanácsai, és miként 1917-ben a kronstadti és egy ideig a pétervári szovjet. ${ }^{54}$

Eszerint 1956-ban egy olyan új rendszer sarjadzott, amelyben az irányítás a közvetlen demokrácia szabályai szerint működő forradalmi tanácsoknak és a képviseleti demokrácia hagyományos intézményeinek, a parlamentnek és a kormánynak az együttmüködésére épült. Ezért fért össze a pártokra alapuló szabad választások követelése a pártellenességgel: mert a forradalom akarta a pártokat, de egyben leszűkítette terrénumukat, minimalizálni törekedett a központi szervek szerepét, és azokat közvetlen, szoros ellenőrzés alatt akarta tartani, miként folyamatos volt a forradalmi tanácsok ellenőrzése és elszámoltatása megválasztóik részéről. A forradalmi tanácsok megelégedéssel és megnyugvással fogadták a többpártrendszer, a koalíciós kormányzás visszaállítását. Mert ez a forma látszott alkalmasnak az országos ügyek intézésére. Nem törekedtek a többpárti kormányt felváltani valamilyen tanácskormánnyal. Annak azonban

52 Á. VARgA - PÁszToR 2001.227-230. A Balassagyarmati Városi és Járási Forradalmi Nemzeti Tanács módosítja a terhesség megszakításáról szóló minisztertanácsi és miniszteri rendeletet. Balassagyarmat, 1956. november 2.

53 BANA-BorbéLY-SZAKÁL-SZAKolCZAI-VöRös 1996. 111. Az ideiglenes Győri Nemzeti Tanács felhívása, 1956. október 28.

54 Haffner 2007.; Broué 2005; Szakolczai 2013. 85.; GetZler 1983. 69-152. 
számos nyoma van, hogy jogukban állónak tartották a kormány ellenőrzését és befolyásolását olyan kérdésekben, amelyekben egyetértés volt különböző forradalmi szervek között, amelyekben tehát meggyőződésük szerint az országos akaratot képviselték - akár ideiglenesen a kormánnyal is szemben.

Más okból, de a forradalmi tanácsokat Bibó ugyanúgy csak a forradalmi időszak, az átmenet intézményeinek tartotta, mint Lenin az orosz forradalom szovjetjeit (amelyeket hatalomra jutása után alá is rendelt a bolsevik pártnak). ${ }^{55}$ Általános a vélemény, miszerint a tanácsok olyan átmeneti forradalmi szervek, amelyek feladata a régi rend lebontása. Szerepük arra az időre korlátozódik, amíg az ancien regime leveri a forradalmat, vagy a forradalom kiépíti a maga új struktúráját. De ötvenhat egy olyan ritka történelmi pillanatnak látszik, amely esélyt adott közvetlen és képviseleti demokrácia, autonóm forradalmi tanácsok és parlamentarizmus együttmüködésére. Mert a kormány élén álló Nagy Imre a forradalmi tanácsokban arra a modellre ismert rá, amelyet 1954-ben az MDP III. kongresszusán tartott beszédében, mint a szocialista demokrácia közigazgatásának, egyben népi hatalmi szervének ideális formáját írt le. 1954-es szövege szerint, amit Rainer János a miniszterelnök elméleti, tudományos igényü programalkotásának nevezett, ${ }^{56}$ azt várta a tanácsoktól, hogy függetlenek és szuverének, a dolgozók tömegszervezetei legyenek. Hogy közvetlenül a lakosságra támaszkodjanak, és képesek legyenek annak mozgósítására. ${ }^{57}$ Azt tekintette feladatának, hogy „az állami tevékenységbe a dolgozók legszélesebb tömegeit, elsősorban a hatalom letéteményesét, a munkásosztályt" vonja be, tegye a hatalom cselekvő részévé. ${ }^{58}$ Mert demokrácia csak ott lehet, ahol a nép gyakorolja a tényleges hatalmat. ${ }^{59} \mathrm{Az}$ a vezetöség, amely a nép nevében gyakorolta a teljhatalmat, az „antimarxista, antileninista volt, klikk volt, amely a pártban diktatúrát valósított meg, elszakította a párttagságot a vezetéstől, a pártot a néptől, amely szembefordult a néppel, terror-uralmat teremtett, a törvénytelenségek tömegét követte el, elárulta az ország elemi érdekeit, függetlenségét stb. - magyarán mondva hazaáruló volt." 60 Úgy látta - legalábbis Snagovból visszatekintve -, hogy „a régi bürokratikus államigazgatási szervezet szétesésével párhuzamosan a széles néptömegek öntevékenysége” azonnal betöltötte a hatalmi-közigazgatási vákuumot, és úgy látta, a forradalmi tanácsok megmutatják, hogy „a bürokráciával terhelt közigazgatás átszervezése terén milyen irányba kell haladni”. Ezeket „a forradalmi harcok során kialakított új hatalmi és kormányzati formákat” október vívmányainak tekintette, és Kádár egyik nagy hibájának tartotta felszámolásukat (illetve a munkástanácsok visszaszorítását). „A forradalmi vívmányok hasznosításának kérdésében nem volt helyes a munkástanácsok, továbbá a forradalmi és nemzeti bizottságok erőszakos felszámolása, az állami és gazdasági szervezet új szerveinek elfojtása". ${ }^{61}$

De nemcsak azért ismerte el a forradalmi tanácsokat, és törekedett azokat beépíteni az államigazgatásba, mert elméletileg úgy látta, hogy általuk valósítható meg a szocialista demokrácia. A szocialista vívmányok és a hatalom megtartására is nagyobb esélyt látott a tanácsok segítségével, amelyek nem támadták a szocialista demokráciát, sőt, ellenkezőleg, annak megvalósításáért küzdöttek, amiről elegendő tapasztalatot szerezhetett az október 28. után a különböző küldöttségekkel folytatott megbeszélésein. Mert 1956-ban általános volt a félelem az ellenforra-

\footnotetext{
55 Biвó 1990b. 202.

56 RAINER 1999. 40.

57 NAGY 1954. 488., 512., 514., 515., 517., 519., 527.

58 NAGY 1954. 499.

${ }^{59}$ NAGY 1954. 512.

${ }^{60}$ Nagy 2006. 130.; LuXemburg 1983. 501.

${ }^{61}$ NAGY 2006. 157.
} 
dalomtól, amitől egyaránt óvott Kéthly Anna, Kovács Béla és Németh László. Nyilván Nagy Imre is félte az ellenforradalmat, és igyekezett minden lehetséges módon biztosítani, hogy a hatalom olyan emberek és intézmények kezében legyen, akik és amik garantálják az elért eredmények megtartását, sőt, továbbfejlesztését. A kormányban mindvégig többségben voltak a marxista alapon álló, szocializmust akaró munkáspárti miniszterek. Sőt, a paraszti szocializmus alapján álló Petőfi Párttal biztosítva volt a szocialista tagok kétharmadnál is nagyobb többsége. De csak remélhette, hogy a kormány politikájával kedvezően tudja befolyásolni a majdani szabad választások eredményét. De ha a választáson mégis olyan demokratikus erő győz, amely polgári, kapitalista fordulatot akar végrehajtani, annak útját állhatják a forradalmi tanácsok, amelyekben meghatározó, sok esetben döntő erőt képviseltek a szocializmus mellett kiálló munkástanácsok. Véleményem szerint ezért (is) akarta azokat Nagy Imre beilleszteni az államigazgatásba.

Így állt elő az a helyzet, amelyben a közvetlen demokrácia intézményei, a forradalmi tanácsok nem támadták, ellenkezőleg, támogatták a képviseleti demokrácia intézményeit, a politikai pártokat, mint az országos ügyek intézőit, mint a központi hatalom letéteményeseit, miközben ragaszkodtak a forradalomban elért eredményeik megtartásához: a helyi ügyek intézéséhez és a központi hatalom ellenőrzéséhez. Annak vezetője pedig szövetségesként tekintett a tanácsokra, amelyeknek nemcsak elismerte demokratikus és szocialista jellegét, függetlenségét és szuverenitását, hanem megtartandó értéknek tekintette őket. Ötvenhat nem egy már volt rendszer visszaállítására irányult, hanem valami sosem volt újat hozott volna létre, ha november 4-én nem gázolják le a szovjet csapatok. Olyan újat, ami nem szerepelt a programokban, mert azok összeállítóinak fogalmuk sem volt róla. Olyan újat, ami a rendkívüli válság legkézenfekvőbb megoldásaként spontán merült fel. Ezért volt ötvenhat forradalom.

\section{FELHASZNÁLT IRODALOM}

Á. VARga, LÁszló - PÁsztor, Cecília (szerk.) (2001): Az 1956-os forradalom Nógrád megyei okmánytára, II/1. Salgótarján, Nógrád Megyei Levéltár.

Ash, Timothy Garton (1990): A lengyel forradalom. A Szolidaritás. Budapest, AB-Beszélő.

BAlogh SÁNDor (1986) (szerk.): Nehézesztendők krónikája, 1949-1953. Dokumentumok. Budapest, Gondolat. BAna, József - Borbély, JÁnos - Szakál, Gyula - Szakolczai, Attila - Vörös, Jenő (1996) (szerk.): Györ, 1956. I. Dokumentumgyüjtemény. Győr, Györ Megyei Jogú Város Önkormányzata.

BENCSIK, PÉTER (2009): Feledésre ítélt reformok? Az MDP KB 1956. júliusi ülése és a „tiszta lap” politikájának néhány történeti problémája. Acta Historica (Szeged), 129. 111-137.

Beránné, Nemes Éva - KaJÁRI, ERzséBet (1989): A magyarországi szakszervezeti mozgalom dokumentumai, 9. kötet. Útkeresés, 1953-1958. Budapest, Népszava.

Bibó, IstváN (1990a): A politikai és alkotmányjogi kibontakozás útja. [Fogalmazvány, 1956. október 30-31.]. In Bibó István: Válogatott tanulmányok, Budapest, Magvető Kiadó. 4. kötet. 157-164.

BiBó, IstváN (1990b): A pártok és a forradalmi szervezetek viszonyáról. In Bibó István: Válogatott tanulmányok, Budapest, Magvető Kiadó. 4. kötet. 197-203.

BiBó, István (1990c): A munkástanácsok és a többpártrendszer. In Bibó István: Válogatott tanulmányok, Budapest, Magvető Kiadó. 4. kötet. 205-212.

Böőr, LÁszló - Gyarmati, György - Horváth, M. Ferenc (2006) (közreadja): Vác '56. Vác 1956-ban és a megtorlás időszakában. Forrásgyüjtemény. Vác, Vác Város Levéltára.

Broué, Pierre (2005): The German Revolution, 1917-1923. Leiden, Brill.

Csomor, Erzsébet - Kapiller, Imre (1996): '56 Zalában. A forradalom eseményeinek Zala megyei dokumentumai, 1956-1958. Zalaegerszeg, Zala Megyei Levéltár.

GetZler, IsRael (1983): Kronstadt, 1917-1921. The fate of a Soviet democracy. Cambridge University Press. Gosztonyi, PÉTER (1989): Föltámadott a tenger... 1956. A Magyar Október története. Budapest, Népszava. 
GYÁNI, GÁвоR (2007): Forradalom, felkelés, polgárháború. 1956 fogalmi dilemmáiról. Budapesti Könyvszemle, 2007. tavasz. 41-49.

Haffner, Sebastian: Az elárult forradalom - Németország, 1918-1919. Budapest, Európa Könyvkiadó.

HóDos, GYöRgY (2005): Tettesekés áldozatok. Koncepciós perek Magyarországonés Közép-Kelet Európában. Budapest, Noran Könyvkiadó.

KozÁK, Gyula - Molnár, Adrienne (1993) (szerk.): „Szuronyok hegyén nem lehet dolgozni!” Válogatás 1956-os munkástanács-vezetők visszaemlékezésiből. Budapest, Századvég Kiadó.

Lomax, Bill (1989): Magyarország 1956. Budapest, Aura.

Luxemburg, Rosa (1983): Marxizmus, szocializmus, demokrácia. Tanulmányok, cikkek, beszédek. Budapest, Gondolat. Az orosz forradalomról. 468-504.

Mandel, David (2011): The Factory Committee Movement in the Russian Revolution. In Ness, Immanuel - Azellini, Dario (szerk.): Ours to master and to Own. Workers' Control from the Commune to the Present. Chicago, Haymarket Books. 104-129.

MÉray, Tiвor (1989): Nagy Imre élete és halála. Budapest, Bibliotéka.

MolnáR, MikLós (1991): Egy vereség diadala. Budapest, Educatio Kiadó.

NAGY, ImRe (1954): Egy évtized. Válogatott beszédek és írások (1948-1954). II. Budapest, Szikra.

NaGy, Imre (2006): Snagovi jegyzetek. Gondolatok, emlékezések, 1956-1957. Szerk.: Szántó László - Vida István. Budapest, Gondolat Kiadó - Nagy Imre Alapítvány.

Pannekoek, Anton (1947): Workers' Councils. http://marxists.org/achive/pannekoe/1947/workers-councils. htm

Rainer, M. János (1999): Nagy Imre. Politikai életrajz, II. 1953-1958. Budapest, 1956-os Intézet.

RAINeR, M. János (2002): 1956 a 20. század történelmében. http://www.rev.hu/ords/f?p=600:2::.:::P2_ PAGE_URI:tanulmanyok/1956/xx_szazad

Ripp, Zoltán (2002): 1956. Forradalom és szabadságharc Magyarországon. Budapest, Korona Kiadó.

SALAMON, KonrÁD: A harmadik útforradalma. http://archiv.xxszazadintezet.hu/rendezvenyek/1956_os_ megemlekezes/salamon_konrad_a_harmadik_ut_f.html

Szabó, Miklós (1992): Demokratikus szocializmus vagy restauráció? Gondolatok 1956 programjáról. In Évkönyv I. Budapest, 1956-os Intézet. 93-96.

SzakolcZai, Attila (2000): Tömegmozgalmak Miskolcon, 1956. október 25-26. In Körösi Zsuzsanna - Standeisky Éva - Rainer M. János (szerk.): Évkönyv, 2000. VIII. Magyarország a jelenkorban. Budapest, 1956-os Intézet. 303-322.

Szakolczai, Attila (2001): Az 1956-os forradalom és szabadságharc. Budapest, 1956-os Intézet.

Szakolczai, Attila (2003): Borsod-Abaúj-Zemplén megye. In Szakolczai Attila - Á. Varga László (szerk.): A vidék forradalma, 1956. I. Budapest, 1956-os Intézet - Budapest Főváros Levéltára. 121-198.

SzakolcZai, Attila (2006): 1956. Budapest, Osiris Kiadó.

SzakolCzaI, Atтila (2006b): Győr-Sopron megye. In Szakolczai Attila (szerk.): A vidék forradalma, 1956. II. Budapest, 1956-os Intézet - Budapest Főváros Levéltára. 141-210.

SzakolCZaI, Atтila (2007) (szerk.): A győri vagongyár munkástanácsa. Győr, 1956. IV. Dokumentumgyüjtemény. Győr, Győr Megyei Jogú Város Önkormányzata.

Szakolczai, Attila (2013) Budapest - Berlin. In Kovács Attila - Romsics Ignác (2013) (szerk.): Sipos '65. Tanulmányok Sipos József 65. születésnapjára. Szeged, 2013.

TакÁcs, Тiвor (2010): Történész a kihallgatószobában. Betekintő 2010/2. http://epa.oszk. hu/01200/01268/00014/takacs_tibor.htm

VARGA, LÁsZló (1989): A forradalom hangja. Magyarországi rádióadások, 1956. október 23.-november 9. Bp., Századvég Kiadó - Nyilvánosság Klub.

VArga, Zsuzsanna (2006): Paraszti követelések 1956-ban. In Estók János (szerk.): 1956 és a magyar agrártársadalom. Budapest, Magyar Mezőgazdasági Múzeum. 81-104.

Zinner, Tibor (2001): A kádári megtorlás rendszere. Budapest, Hamvas Intézet. 